\title{
Die geologie van 'n gebied in die Kangogroep
}

\author{
Outeurs: \\ Ryan Nel, \\ Al Odendaal, \\ GJB Germs, \\ HE Praekelt \\ Affiliasie: \\ Departement Geologie, \\ Universiteit van die Vrystaat \\ Posbus 339, Bloemfontein, \\ 9300 \\ Korresponderende outeur: \\ $\mathrm{R} \mathrm{Nel}$ \\ E-pos: ryan2nel@gmail.com \\ Hoe om hierdie artikel aan \\ te haal: \\ Ryan Nel, Al Odendaal, \\ GJB Germs, HE Praekelt, \\ Die geologie van 'n \\ gebied in die Kangogroep, \\ Suid-Afrikaanse Tydskrif \\ vir Natuurwetenskap en \\ Tegnologie 38(1) (2019). \\ https://doi.org/10.36303/ \\ SATNT.2019.38.1.772 \\ Kopiereg: \\ (c) 2019. Authors. \\ Licensee: Die Suid- \\ Afrikaanse Akademie vir \\ Wetenskap en Kuns. \\ Hierdie werk is onder \\ die Creative Commons \\ Attribution License \\ gelisensieer.
}

\begin{abstract}
The geology of an area in the Cango Group: The geology of the Cango Group represents a complex carbonate-siliciclastic succession. The compilation of a more detailed geological map of a small area led to the revision and re-interpretation of the stratigraphy, sedimentology and structure of this sedimentary succession. This aided in better understanding the factors involved during the deposition of this succession.
\end{abstract}

Die geologie van die Kangogroep, geleë $27 \mathrm{~km}$ noord van Oudtshoorn, verteenwoordig 'n ingewikkelde opeenvolging wat uit karbonaat en silisiklastiese gesteentes bestaan. Daar bestaan verskeie navorsingsvrae oor die stratigrafie, sedimentologie en struktuur van die gebied. Hierdie opeenvolging vorm deel van die Saldania-gordel, wat tydens die Neoproterosoïkum tot vroeë Palaosoïkum gevorm het. Die opeenvolging is ontbloot as 'n venster en word deur die jonger Kaapsupergroep-gesteentes, wat Ordovisium tot Karboon in ouderdom is, omring. Die Kangogroep-gesteentes is by verskeie geleenthede deur tektonisme geaffekteer, veral tydens die Pan Afrikaanse Orogenese wat tydens die Neoproterosoïkum tot vroeë Palaosoïkum plaasgevind het. Kartering van die studiegebied, waartydens stratigrafiese, sedimentologiese en strukturele ondersoeke gedoen is, het verskeie nuwe geologiese verskynsels uitgelig. Die Kangogroep is opgedeel in die onderste Matjiesrivierformasie en die oorliggende Groenefonteinformasie. Die Matjiesrivierformasie bestaan hoofsaaklik uit afwisselende karbonaat en silisiklastiese gesteentes, terwyl die Groenefonteinformasie uit meer silisiklastiese gesteentes bestaan. Die twee formasies word deur die Groenefontein-diskordansie geskei, wat'n periode met 'n lae seevlak verteenwoordig. Die Matjiesrivierformasie is verder onderverdeel in die Nooitgedagt- en die oorliggende Kombuislede. Beide die lede bevat strukture soos verskuiwings en plooie. Daar is voorheen vermoed dat die Nooitgedagtlid en Kombuislid van die Matjiesrivierformasie deur 'n antiklinale plooi gedupliseer is. Nadere ondersoek van die Matjiesrivierformasie het getoon dat daar egter geen antiklinale plooi voorkom nie en ook geen duplisering van die lae soos wat daar verwag sou word met die vorming van 'n antiklien nie. Daar is ook vasgestel dat die Nooitgedagtlid uit ' $n$ veel dikker opeenvolging bestaan as wat voorheen beskryf is en verskeie oervalleie is ontdek wat geassosieer word met lateraalstrekkende diskordansies. Hierdie diskordansies maak dit moontlik om die Matjierivierformasie verder in diskordansie-gebonde opeenvolgings te verdeel. Die diskordansie-gebonde opeenvolgings maak dit moontlik om die geologiese prosesse wat geheers het tydens die afsetting van die Matjiesrivierformasie, uit te pluis.

Die oorliggende Groenefonteinformasie is opgedeel in die onderste Nelsrivierlid en boonste Brakkerivierlid. Die gesteentes van die Groenefonteinformasie toon intensiewe plooiing met verskeie plooias-rigtings. Die plooiing van die gesteentes hou moontlik verband met 'n verskuiwing wat die Kangogroep aan die noordelike kant van die studiearea begrens. Die Groenefonteinformasie is veel dikker en meer homogeen as die onderste Matjiesrivierformasie, en dié formasie bevat ook geen ooglopende diskordansies nie. Die Groenefonteinformasie kan dus nie opgedeel word in diskordansie-gebonde opeenvolgings nie. Daar word vermoed dat die diskordansievlakke wat in die Matjiesrivierformasie en aan die basis van die Groenefonteinformasie voorkom, toegeskryf kan word aan tektoniese en glasiale prosesesse wat geheers het tydens die Neoproterosoïkum.

Nota: 'n Seleksie van referaatopsommings: Studentesimposium in die Natuurwetenskappe, 25-26 Oktober 2018, SA Akademiegebou, Pretoria, Suid-Afrika. Gasredakteurs: Prof Rudi Pretorius (Departement Geografie, Universiteit van Suid-Afrika); Prof Chris Swanepoel (Departement Besluitkunde, Universiteit van Suid-Afrika); Me Andrea Lombard (Departement Geografie, Universiteit van Suid-Afrika) 